\title{
Upper Primary Learners' Level of Critical Thinking Skill and Its Effect on Students' English Language Achievement in Relation with Sex
}

\author{
Yohannes Sisay Molla \\ Assistant Professor, Woldia University, Woldia, Ethiopia \\ yohannestsehay@rocketmail.com
}

\begin{abstract}
The present study examined the nature of upper second cycle elementary school students' critical thinking ability, investigated the correlation of critical thinking skill with learners' English language achievement and sex, and explored the effect of critical thinking ability on learners' English language achievement. The study involved 99 grade seven students from two government full cycle primary schools in Woldia town. In order to gather data, standardized critical thinking test was administered and semester based learners' English language achievement scores were used. So, T-test, Pearson product moment correlation and linear regression ware employed to analyze the data. Results of t-test applied to analyze the critical thinking test results revealed that participants' level of critical thinking skill was very low, and the mean difference between female and male students' critical thinking score was not statistically significant. However, the result of Pearson product moment correlation coefficient showed that there was a positive significant correlation between the critical thinking ability and English language achievement; whereas, correlation was not found between learners' critical thinking proficiency and sex. The finding from the linear regression also exposed that learners' critical thinking proficiency could predict approximately $36 \%$ of learners' English language achievement. Finally, the researchers made conclusions and forwarded recommendations based on the findings.
\end{abstract}

Keywords: Achievement; Critical Thinking; Elementary School; Foreign Language; Upper Second Cycle;Sex

\section{Introduction}

Education is a key of life. It is the formal and informal processes of teaching and learning used to develop a person's knowledge, skills, attitudes, understanding, etc., in a certain area or domain. Thus, scholars confirmed that the absolute purpose of education is getting learners ready for the challenges and uncertainties of their future life. In other words, it is believed that education equips learners with the necessary skills and knowledge that helps them to cop up with the fast growing technology and scientific discoveries. These skills comprise enormous ideas like creativity, innovation, problem solving, communication, collaboration, teamwork, and critical thinking (Hove, 2012). The practice of producing creative and novel ideas has been noted as a fundamental target and core principle of the contemporary education system (Beaumont, 2010). To put it more explicitly, the notion of education is to produce ingenious citizens who are reflective, creative and critical thinkers. Robinson, as cited in Cotton (1991), for example, states in her 1987 practicum report:

Teaching children to become effective thinkers is increasingly recognized as an immediate goal of education....If students are to function successfully in a highly technical society, then they must be equipped with lifelong learning and thinking skills necessary to acquire and process information in an ever-changing world (p. 16).

It has been long since scholars have identified the relevance of critical thinking skills as a final product of student learning. For instance, Marin and Halpern (2011) argued that the primary rational of formal education is to enhance learners' critical thinking skills because the 
capacity to think critically is indispensable to be successful in the modern world where the tempo for the creation of new knowledge is increasing in alarming rate. Besides, Snyder and Snyder (2008), noted that critical thinking skills are essential because they serve as a vehicle for educating the mind and empower students to handle social, scientific, and practical problems effectively. Especially, in the past two or three ten years, scholars and educators have emphasized the value of teaching critical thinking within and across academic areas (Iakovos, 2011; Lai, 2011; Tung and Chang, 2009; Bracken et al., 2009). Moreover, "Critical thinking ability has been identified as one of the constructs which has been proven to be a good predictor of academic performance." (Tsui; Elias; Freire, cited in Keihaniyan, 2013: 25)

More recently, the Partnership for 21st Century Skills has identified critical thinking as one of several learning and innovation skills necessary to prepare students for post-secondary education and the workforce. That is why notional shifts in the education system tend to value critical, creative and innovative ideas. It also emphasizes over the appropriateness and practicality of critical thinking in education (Facione, 2011; Paul, 2004). Therefore, the ability to think critically is a crucial life skill. It is also strongly believed that enhancing learners' critical thinking capacity on their own learning process can assist them to improve in their learning. Critical thinking is the component skill of higher-order thinking that prop up higher order learning skills which in turn allow students to accomplish higher levels of language proficiency (Renner, 1996). According to Tung and Chang (2009), scholars have argued on the soundness of incorporating the instruction of critical thinking skills in EFL lessons, since such skills are increasingly required for success in a knowledge-based society. To strengthen the idea of teaching critical thinking skills in the language classroom, Iakovos (2011: 82) mentioned that language classes, in particular, are more suitable for the instruction of critical thinking skills, because of the context and pedagogy that language is taught: richness in material and the use of interactive approaches.

Research evidence has shown that critical thinking and language development are closely related. Such close relationships between language and thinking skills have long been recognized by theorists and educators (Chomsky, 1993; Piaget, 2005; Vygotsky, 1962). For instance, as Shahini and Riazi (2011: 171) noted, "Language is a mental tool that each member of the social community (classroom) uses to think and it is through language and communication that abstract thinking becomes possible." It is also believed that children come to know the world through language. Shirkhani and Fahim (2011) also claim that the improvement of learners' critical thinking skills is necessary, for the importance it has in the development of effective language learning. Therefore, helping learners to acquire critical thinking skills has to be regarded as one of the everyday jobs of English as a foreign language teachers (Liaw, 2007). They can do this task through various ways, including choosing appropriate materials, using appropriate exercises, and designing and implementing standardized and relevant assessments.

However, various scholars provided various definitions for term critical thinking. Ennis (1985), for instance, defined critical thinking as it is "reflective and reasonable thinking that is focused on deciding what to believe or do." On the other hand, Cotton (1991) defined critical thinking as it is "the process of determining the authenticity, accuracy, or value of something; characterized by the ability to seek reasons and alternatives, perceive the total situation, and change one's view based on evidence."

In addition to Ennis and Cotton, Keihaniyan (2013: 25) used the term critical thinking as it is: 
a way of deciding whether a claim is true, partially true, or false. Critical thinking is a process that leads to skills that can be learned, mastered and used. Critical thinking is a tool by which one can come about reasoned conclusions based on a reasoned process. This process incorporates passion and creativity, but guides it with discipline, practicality and common sense.

According to Facione and Facione (2009), "Critical thinking is the process of making purposeful, reflective and fair-minded judgments about what to believe or what to do. Individuals and groups use critical thinking in problem solving and decision making." Furthermore, Lai (2011: 2) also noted that critical thinking incorporates various skills like "analyzing arguments, making inferences using inductive or deductive reasoning, judging or evaluating, and making decisions or solving problems."

Critical thinking is a learned ability that must be taught. Thus, experts have argued that critical thinking skills are not likely to develop spontaneously or innately. To strengthen this, Lombard as cited in Hove (2011:21) cautioned that "Critical thinking is not a product of simple growth and maturation; instead, critical thinking skills must be explicitly taught and consistently practiced." Furthermore, Iakovos (2011) noted that critical thinking is a skill which can be learned in the classroom, since the ability to think critically constitutes a kind of intelligence which students do not necessarily or naturally acquire. By contrast, it is believed that teachers must take a directive role in initiating and guiding critical thinking, since it is considered as a learnable skill. The teaching of critical thinking needs to be well organized and consistent, and it must be given all the way through the entire educational hierarchies. Thus, Beyer (2008) encouraged schools to constantly familiarize learners of all ages to thinking strategies. Applying various thinking strategies effectively and consistently predicts considerably what learners learn, produce and achieve in class. Thompson and Evans (2005: $\mathrm{x}$ ) also claimed that "Teaching children to 'think' has now become an acceptable part of educational practice."

On the contrary, Shirkhani and Fahim (2011) argued that thinking skills and language learning are often treated as distinct practices in actual classrooms although there is massive understanding among theorists and educators about the invaluable importance of critical thinking skills in learners' over all lifelong success and language development to be specific. Similarly, Pica (2000) stated that in the tradition of English language teaching methodology, the integration of language and thinking skills has been peripheral. The existing educational trend which focuses on test scores constraints teachers' capacity to deal with critical thinking in the classroom (Snyder and Snyder, 2008). Giving more emphasis on teaching to enhance the test result of learners distracts the teaching-learning process from learners self construction of knowledge and places the emphasis on memorization of facts presented by teachers. If the focus is on learning, students should be given the autonomy and accountability to explore content, analyze resources, and apply information.

Similarly, Ethiopian students are used to rote learning, so the use of critical thinking skills is not part of their daily routine. Linked to this argument, Dessie (n.d.: 28) found out in his study that "The students' disposition towards critical reading tasks and intellectual standards of critical thinking was found very limited and the students were not interested to question writers while reading." Furthermore, he learned from the intervention that students gave little attention to carry out critical reading tasks. Students have been trying to read for a mere comprehension. As a result, Dessie concluded that learners had little or no insights concerning the logical principles of critical thinking. 
Furthermore, in the summary report of the Institute of International Education briefing paper (2012), various groups of participants of the conference on 'Enhancing the Quality of English Language Education in Ethiopia' reflected on issues like a continuous deterioration in the quality of English language education, the production of exam-oriented students who do not internalize their learning; and the declining tendency in critical thinking.

The above mentioned problems have instigated the researchers to investigate upper elementary school learners' level of critical thinking and the relationship between critical thinking with English language achievement and sex. Therefore, the researchers formulated the following research hypotheses.

\section{Null Hypothesis}

- There is no statistically significant difference between female and male students' score on the critical thinking test.

- There is no correlation between students' English language achievement and their critical thinking skill.

- There is no association between learners' critical thinking proficiency with their sex (gender).

- There is no significant prediction capability between learners' critical thinking ability and their English language achievement.

\section{Methodology}

\subsection{Design of the Study}

This research followed a quantitative research approach and an explanatory, correlation, research design. In order to gather data related to the research questions, standardized critical thinking test was administered and learners' English language achievement scores were used. The critical thinking test is adapted from the Test of Critical Thinking (TCT) which is a researcher developed test at the College of William and Mary. The scores of EFL achievement were taken from the students' cumulative results records in the first semester of 2010 E.C. (2017/2018 G.C.). All of the respondents were further given a test on critical thinking skills in reading at the beginning of the second semester of the same academic year.

\subsection{Participants}

Students from two schools were selected for data gathering. The researcher used a simple random sampling technique to select one section of students from each school. As a result, $7^{\text {th }}$ C was chosen from Etege Tayitu Bitul while section D was chosen from Woldia Full Cycle Primary School. In general, a total of ninety-nine grade seven students participated in this study.

\subsection{Data Collection Instruments}

A critical thinking test will be used to measure the learners' critical thinking skills and to identify the group (control or experimental) that acquires it. The test will be adapted from the Test of Critical Thinking (TCT) which is a researcher developed test at the College of William and Mary. It is specifically designed for measuring the effects of curriculum interventions with gifted and general education students in upper elementary grades (Bracken et al., 2003). The test consists of 45 items, arranged across ten brief scenarios. Each scenario is followed by 3 to 6 critical thinking items. A multiple-choice item format is used for all scenarios, with four 
options presented per item (i.e., one keyed response and three foils). The internal consistency of the instrument was .81 .

\subsection{Data Analysis}

The data is analyzed quantitatively, and the Statistical Package for the Social Sciences (SPSS), Version 20.0 was used for analysis. Both the result of critical thinking test and first semester achievement scores of learners were used for data analysis purpose. T-test, correlation and linear regression were employed. The t-test is used to identify the level of learners' critical thinking and the statistical difference of critical thinking score between female and male students. Since the main purpose of this study was to describe the degree of association between learners' English language achievement and critical thinking skill, correlation is calculated. In this study, the correlation was represented by a participant's performance on the test of critical thinking and their semester based English language achievement and describing the degree of relationship between the variables. Therefore, the correlation was calculated using the Pearson Product Moment Coefficient. Finally, linear regression is used to see the effect of critical thinking on English language achievement.

\section{Results}

As it is displayed in table 1 which is for the descriptive statistics, the mean of the critical thinking test was calculated to be $11.21, \mathrm{SD}=5.48$ with a range of $1-24$. The total possible score was 45 for the critical thinking test. In addition to the critical thinking, the mean of the language achievement score was 69.64, SD $=15.08$, range 31-97. The total score for learners' language achievement was 100 .

Table 1. Descriptive Statistics

\begin{tabular}{|l|c|c|c|c|c|r|r|}
\hline & $\mathrm{N}$ & Range & Minimum & Maximum & Mean & $\begin{array}{c}\text { Std. } \\
\text { Deviation }\end{array}$ & Variance \\
\hline CTT & 99 & 23.00 & 1.00 & 24.00 & 11.2121 & 5.47587 & 29.985 \\
EL Achiev. & 99 & 66.00 & 31.00 & 97.00 & 69.6364 & 15.08307 & 227.499 \\
\hline
\end{tabular}

As it is displayed in table 2, the mean of the male students English language achievement (which is 69.29) is slightly lower than female students' (69.93). Whereas, the mean score of male students for the test of critical thinking skill is 11.62, and it is slightly higher than female learners' mean score which is 10.87 for the same test. However, the Levene's Test for Equality of Variances identified that no statistical evidence was found on the difference between the mean of male and female students in relation to critical thinking skill $(\mathrm{p}=0.499, \mathrm{t}=.678, \mathrm{df}=$ 97). Since the statistical significance of Levene's Test for the critical thinking is greater than 0.05 ( $\mathrm{p}>0.05$ ), it can be stated that the mean differences between female and male students are not statistically significant. Therefore, the null hypothesis is accepted since p-value is greater than 0.05 . This means that at $5 \%$ significance level, the claim that there is no statistically significant difference between female and male students' score on the critical thinking test is right.

Table 2. Learners' level and their group mean of critical thinking Group Statistics 
Independent Samples Test

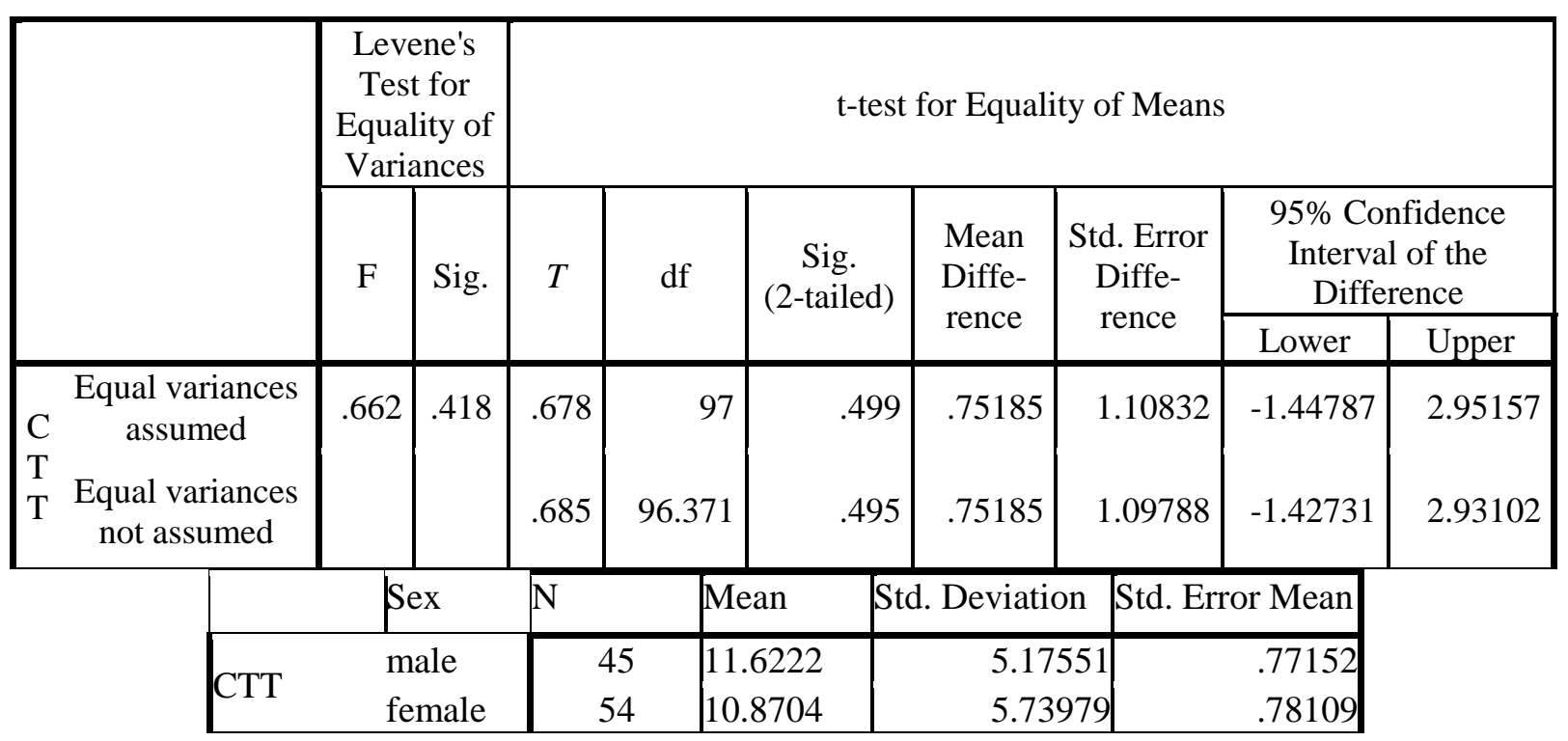

The Pearson correlation coefficients are employed in order to find out if there is any significant relationship between learners' critical thinking skill and their English language achievement. As displayed in Table 2, a positive strong significant relationship (correlation coefficient .598, significance at the 0.01 level) is found between the score for critical thinking and foreign language achievement. Hence, the null hypothesis is rejected in this case as pvalue is found less than 0.01 .

On the contrary, according to the results signified in the table under here, there is no significant association between learners' sex and critical thinking skills and also between their sex and English language achievement. The Pearson product-moment correlation coefficients of sex with critical thinking skills and sex with English language achievement are found to be $\mathrm{r}=-.069, \mathrm{p}=0.499$; and $\mathrm{r}=0.021, \mathrm{p}=0.835$, respectively, and on both cases, $\mathrm{p}>0.01$. Therefore, since the $\mathrm{p}$-value is greater than 0.05 , the null hypotheses are accepted or found to be true in relation to sex with critical thinking ability and sex with English language achievement.

Table 3. Correlation among learners' English language achievement, critical thinking skill and their sex

\begin{tabular}{|c|c|c|c|c|}
\hline & & CTT & EL Achiev & Sex \\
\hline \multirow{3}{*}{ CTT } & Pearson Correlation & 1 & $.598 * *$ & -.069 \\
\hline & Sig. (2-tailed) & & .000 & .499 \\
\hline & & 99 & 99 & 99 \\
\hline \multirow{3}{*}{ EL Achiev. } & Pearson Correlation & $.598 * *$ & 1 & .021 \\
\hline & Sig. (2-tailed) & .000 & & .835 \\
\hline & $\mathrm{N}$ & 99 & 99 & 99 \\
\hline
\end{tabular}

The data is further analyzed and regression analyses were made in order to find out what percent of variability in learners' English language achievement can be accounted for their skill of critical thinking. The results signified that learners' total score of critical thinking skill is a 
positive predictor of their English language achievement. Therefore, the total scores of critical thinking can predict 35 percent of the learners' English language achievement. The $\mathrm{R}$ value is 0.598 which indicates the correlation coefficient between CT and English language achievement, and the square value of $\mathrm{R}$ is 0.357 . This refers that about $36 \%$ of the variation in learners' English language achievement can be explained by taking their critical thinking skills into account.

Table 4. Critical thinking on learners' English language achievement

Model Summary

\begin{tabular}{|l|l|r|r|r|}
\hline Model & \multicolumn{1}{|c|}{$\mathrm{R}$} & R Square & Adjusted R Square & Std. Error of the Estimate \\
\hline 1 & $.598^{\mathrm{a}}$ & .357 & .350 & 12.15626 \\
\hline
\end{tabular}

\section{Discussion}

Currently, enhancing learners' critical thinking skills has been widely considered as one of the most fundamental objectives of education (Iakovos, 2011). However, the idea of effective amalgamation of critical thinking skills with the teaching of English as a foreign language is a recent phenomenon. This belief is based on the empirical evidences that there is a positive degree of association between knowledge and thinking and between language learning and thinking processes. Having said this, the result of the study is discussed here after in relation with the literature and research findings.

T-test is administered to evaluate the level of learners' critical thinking ability and to understand the effect of gender on learners' English language achievement and critical thinking skill. According to Cohen et al. (2007: 543), "T-test is used to discover whether there are statistically significant differences between the means of two groups, using parametric data drawn from random samples with a normal distribution". As clearly displayed in the result section, the overall mean score of learners' critical thinking is calculated to be 11.21 and $\mathrm{SD}=$ 5.48. The standard deviation refers that the two-third of students' score is approximately within the range of 6-17 out of 45; and these figures implies that the learners' performance of critical thinking is very low. As Grosser and Nel (3013) quoted from Halpern; Halx and Reyblold, the poor performance that participants accomplished on the test of critical thinking perhaps signifies that they have not yet completely acquired the interconnected cognitive and metacognitive skills that are compulsory to perform critical thinking.

Besides the level of learners' critical thinking ability, the t-test statistics for the group mean revealed that the mean difference between male and female students on the critical thinking test score is not statistically significant. This means that sex does not have any influence on learners' critical thinking capacity. The result matches with the finding of AbuDabat (2013: 155) that "there is no significant statistical difference in the achievement of critical thinking skills attributed to gender." In addition to the t-test, the Pearson productmoment correlation coefficient showed that there is no significant relationship between learners' sex with their critical thinking score. Nordin and Dakwah (2015) also reached at a similar result that there is no significant association between genders and the students' level of critical thinking skills. 
In the literature it is highly acknowledged that language and thought, language and cognition, and language and critical thinking are highly interrelated. In line with the literature, the Pearson product-moment correlation coefficients of the study showed significant and positive correlations between the total score for the test of critical thinking with the semester based assessment score for learners' English language achievement. As the score for critical thinking increased the score for English language achievement increased, or conversely as the score for English language achievement increased the score for critical thinking increased. In other words, those who score higher on the critical thinking test are found to be higher achievers in the English language assessment. This finding, however, is quite in line with that obtained in other studies (Grosser and Nel, 2013; Junining, 2015; Liaw, 2007; Rashid and Hashim, 2008), and with a substantial theoretical and empirical base in the literature demonstrating the association of critical thinking with students' foreign language achievement (e.g., Ghanizadeh and Mirzaee, 2012; Iakovos, 2011; Lia, 2011).

However, some studies have come up with different findings. For instance, unlike previously mentioned researchers, Tung and Chang (2009) found a different result that the proficiency of students' English language did not correlate with their critical thinking proficiency: in both the pretest and posttest of California Critical Thinking Skills Test. Likewise, Nordin and Dakwah (2015: 46) conducted a correlation study and they found out that there was no significant relationship between level of critical thinking skills and CGPA of students at the significance level of .05.

Finally, the data is analyzed with a multiple linear regression in order to calculate the effect size of critical thinking ability on learners' English language achievement. In the study, it is found out that learners' level of critical thinking can predict about $35 \%$ of their English language achievement. Thus, it can be strongly claimed that critical thinking is a crucial factor in explaining EFL learners' levels of language proficiency. Similarly, in their study Ghanizadeh and Mirzaee (2012: 463), have come up with a similar but not identical result that critical thinking is a predictor variable for achievement, and it was also revealed that "EFL learners' CT can predict about $28 \%$ of their achievement." Thus, the pedagogical implication is that critical thinking skill can be taught in the classroom to improve the achievement of students' English language.

\section{Conclusions}

Taking the results found into account, the following conclusions were drawn.

The study revealed that upper elementary school learners' critical thinking ability is found very low. In addition to this, it was found out that learners' sex does not influence the acquisition of critical thinking skills. These findings helped us to conclude that the current education system is not effective enough to enable learners to improve their critical thinking ability. The English language instruction does not improve learners' critical thinking skills; instead, it encourages learners' memorization of language rules so that they can pass exams.

Unlike the low level of participants' critical thinking skill, a positive correlation is found between learners' English language achievement with their critical thinking ability. Besides the correlation between these two variables, it is also discovered that the level of learners' English language achievement can be predicted by their critical thinking skill. Therefore, the researchers concluded that the integration of critical thinking activities in the English language learning strategies can help students to enhance their way of thinking and English language achievement. In other words, critical thinking and language skills are the two faces of the same 
coin. The effective acquisition or learning of these two skills cannot be achieved discretely: therefore, the enhancement of students' critical thinking capacity should be inculcated in the strategies and lessons for students' English language learning.

\section{Recommendations}

- The strategy of enhancing learners' critical thinking ability has to be incorporated in a foreign language teaching pedagogy.

- English Language Teachers should have been given sustainable trainings on the pedagogy of using strategies to promote critical thinking in language learning and to teach language for reasoning.

- The old cycle of transmission pedagogy which emphasizes on improving learners' test scores should be replaced with critical thinking pedagogy in language education. This may promote learners to thoroughly discover themselves in the process of language learning, and develop an understanding of using language appropriately to reason.

\section{References}

Abu-Dabat Z (2013). The Achievement and Development of Critical Thinking Skills in the Arabic Language of Adolescent Pupils with reference to the Primary Stage throughout Jordan. International Journal of Humanities and Social Science; 3(5); pp. 155-162.

Beaumont J (2010). A Sequence of Critical Thinking Tasks. Feature Article. TESOL Journal, 1(4); pp. 1-22

Bracken B, Bai W, Fithian E, Lamprecht M, Little C, Quek C (2003). The Test of Critical Thinking. Williamsburg, VA: Center for Gifted Education. The College of William and Mary.

Bracken B, Brown E, Feng A, VanTassel-Baska J (2009). A Longitudinal Study of Enhancing Critical Thinking and Reading Comprehension in Title I Classrooms. Journal for the Education of the Gifted; 33(1), pp. 7-37. Prufrock Press Inc., http://www.prufrock.com Chomsky N (1993). Language and Thought. California: Moyer Bell

Cohen L, Manion L, Morrison K (2007). Research Methods in Education (6 $6^{\text {th }}$ ed.). New York: Taylor \& Francis Group

Cotton K (1991). Teaching Thinking Skills. School Improvement Research Series

Dessie Wondifraw M. (n. d.). The Effect of Infusing Intellectual Standards of Critical Thinking on EFL Students' Critical Reading Performance: Haramaya University, Ethiopia Int. J. Innovative Ideas (IJII) 2232-1942 @ www.publishtopublic.com

Ennis R (1985). A Logical Basis for Measuring Critical Thinking Skills. Educational Leadership, 44-48.

Facione PA, Facione NC (2009). The Holistic Critical Thinking Scoring Rubric - HCTSR: A Tool for Developing and Evaluating Critical Thinking. Millbrae CA: California Academic Press

Facione PA (2011). Critical Thinking: What It Is and Why It Counts: Two parallel rational decision making systems associational and criterion automatic and well trained, reflective. The California Academic Press, Millbrae, CA

Ghanizadeh A, Mirzaee S (2012) EFL Learners' Self-regulation, Critical Thinking and Language Achievement. International Journal of Linguistics; 4 (3), pp. 451-468. ISSN: 1948-5425. www.macrothink.org/ijl 
Grosser MM, Nel M (2013). The Relationship between the Critical Thinking Skills and the Academic Language Proficiency of Prospective Teachers. South African Journal of Education; 33(2), pp. 1-17. Retrieved at: http://www.sajournalofeducation.co.za

Hove G (2011) Developing Critical Thinking Skills in the High School English Classroom: A Research Paper Submitted in Partial Fulfillment of the Requirements for the Master of Science Degree in Education. The Graduate School University of Wisconsin-Stout; May, 2011

Iakovos T (2011) Critical and Creative Thinking in the English Language Classroom. International Journal of Humanities and Social Science; 1(8), pp. 82-86. July 2011

Institute of International Education (2012). An IIE Briefing Paper: Enhancing the Quality of English Language Education in Ethiopia: Report on a Future Search Conference. Institute of International Education, MoE, and Ambo University

Junining E (2015). The Relationship between Intelligence, Critical Thinking Skills in Reading and EFL Proficiency among EFL Learners. Retrieved at: http://fib.ub.ac.id/

Lai ER (2011) Critical Thinking: A Literature Review Research Report. Pearson, Available at: http://www.pearsonassessments.com/research

Liaw M (2007) Content-Based Reading and Writing for Critical Thinking Skills in an EFL Context. English Teaching \& Learning, 31(2), pp. 45-87

Marin LM, Halpern DF (2011) Pedagogy for Developing Critical Thinking in Adolescents: Explicit Instruction Produces Greatest Gains. Thinking Skills and Creativity; 6, pp. 113; Elsevier Ltd. doi:10.1016/j.tsc.2010.08.002

Nordin N, Dakwah J (2015) Critical Thinking as a Predictor of Students' Academic Achievement: A Study on Islamic Studies Students at Pahang Islamic College, Sultan Ahmad Shah, Kuantan. Journal of Education and Social Sciences, V. 1

Paul RW (2004). Critical Thinking: What Every Person Needs to Survive in a Rapidly Changing World. California: Sonomata State University, Centre for Critical Thinking.

Piaget J (2005). The Language and Thought of the Child ( ${ }^{\text {rd }}$ Ed.). Taylor \& Francis e-Library, ISBN: 0-203-99273-3. http://www.ebookstore.tandf.co.uk/

Pica T (2000). Tradition and Transition in English Language Teaching Methodology. System; 29, pp. 1-18.

Rashid RA, Hashim RA (2008). The Relationship between Critical Thinking and Language Proficiency of Malaysian Undergraduates. Edith Cowan University Research Online, EDU-COM International Conference. 19-21 November 2008; pp. 373-384. htt://ro.ecu.edu.au/

Renner CE (1996, February-March). Enrich Learners' Language Production Through ContentBased Instruction. Paper presented at a National Conference on Linguae Nuova Didattica, Modena, Italy. (ERIC Document Reproduction Service No. ED 411 694).

Shirkhani S, Fahim M (2011) Enhancing Critical Thinking in Foreign Language Learners. $1^{\text {st }}$ International Conference on Foreign Language Teaching and Applied Linguistics, May 5-7 2011 Sarajevo

Snyder LG, Snyder MJ (2008). Teaching Critical Thinking and Problem Solving Skills. The Delta Pi Epsilon Journal; 1(2), pp. 90-99, Spring/Summer, 2008.

Thompson G, Evans H (2005). Thinking It Through: Linking Language Skills, Thinking Skills and Drama. Great Britain: David Fulton Publishers Ltd. ISBN: 1843121905

Tung C, Chang S (2009). Developing Critical Thinking through Literature Reading. Feng Chia Journal of Humanities and Social Sciences, No.19, pp.287-317, 